\title{
FUNGAL PATHOGENS OF THE GENUS Fusarium IN WINTER WHEAT Triticum aestivum L. PROTECTED WITH FUNGICIDES IN NORTH-EASTERN POLAND
}

\author{
Agnieszka Pszczółkowska, Adam Okorski, Jacek Olszewski, Joanna Jarmołkowicz \\ University of Warmia and Mazury in Olsztyn, Department of Diagnostics and Plant Pathophysiology \\ Plac Łódzki 5, 10 - 727 Olsztyn, Poland \\ e-mail: agnieszka.pszczolkowska@uwm.edu.pl
}

Received: 22.06 .2012

\begin{abstract}
Various diagnostic methods were used to evaluate the effect of fungicide protection on the prevalence of pathogenic fungi in wheat grain. Winter wheat cv. Nutka and Zyta was grown during a field experiment established in the Production and Experimental Station in Bałcyny in 2006-2007. The experimental factor was chemical crop protection: epoxiconazole, kresoxim-methyl and fenpropimorph applied at growth stages BBCH 33-35 as well as dimoxystrobin and epoxiconazole applied at BBCH 51-53. In this experiment, microscopic observations and conventional PCR assays were used as complementary methods. The quantification of Fusarium poae DNA by qPCR demonstrated the effectiveness of chemical protection against the analyzed fungal species. Lower monthly precipitation levels and higher daily temperatures intensified grain infections, in particular those caused by $F$. poae. A significant correlation was determined between the number of $F$. poae cultures isolated from winter wheat grain and the quantity of pathogenic DNA in grain identified by qPCR. Grain infections caused by $F$. poae lowered yield and thousand seed weight.
\end{abstract}

Key words: wheat, grain, Fusarium, PCR, real-time PCR (qPCR), conventional PCR.

\section{INTRODUCTION}

Wheat (Triticum aestivum L.) is susceptible to fungal infections which lower productivity and deteriorate yield quality (S c h e id e r et al. 2009). Fungi of the genus Fusarium attack open flowers of wheat plants during a critical growth stage which determines grain yield (F i s c h e r, 1985). Plants are infected at different growth stages, and Fusarium head blight (FHB) is the most damaging disease which lowers grain yield, deteriorates yield quality and leads to the accumulation of various mycotoxins in crop plants (Golińs ki et al. 2010). FHB is caused by more than
20 species of the genus Fusarium, and the most commonly encountered taxa in Poland and in Europe are $F$. avenaceum, $F$. culmorum, $F$. graminearum, $F$. poae and $F$. sporotrichoides (K i e c a $\mathrm{n}$ a et al. 2012, L eslie and Summere11,2006; Pląskowska and Chrzanowska-Drożd ż, 2009).

Chemical substances provide effective crop protection. Many fungicides eliminate pathogens, reduce their spread and inhibit the progression of crop diseases (Kryczyński, 2002). The pathogen has to be correctly identified for fungicide treatments to deliver optimal effects. Unambiguous identification of pathogens based on the observed symptoms may be difficult, in particular at early stages of disease when various pathogens may produce similar symptoms (Nichols on et al. 1998).

In microscopic analyses, pathogens are difficult to identify based on their morphological traits due to similarities in species description, the absence of unique morphological structures and the predominance of fast-growing species in fungal colonies. In conventional isolation methods, only a fraction of the total microbial population is revealed ( $\mathrm{Kw}$ a ś $\mathrm{n}$ a and $\mathrm{B}$ a t e $\mathrm{m}$ a $\mathrm{n}$, 2009). Molecular methods based on polymerase chain reaction (PCR) offer superior detection capabilities (S chilling et al. 1996). The PCR technique is a sensitive and highly-specific tool for detecting and identifying pathogens in plant tissues ( $\mathrm{Nichols} \mathrm{on}$ et al. 2003). PCR and real-time PCR support fast identification of species ( $\mathrm{Mule}$ et al. 2005). Molecular techniques have led to the reorganization of fungal taxonomy, and they support observations of disease progression (K o n c z et al. 2008).

Numerous attempts to detect and identify fungi of the genus Fusarium in grain and plant tissue have accumulated into an extensive body of research. Spe- 
cific primers and probes have been developed for identifying pathogens that attack crop plants at different stages of growth (K u lik, 2008; K u lik et al. 2011; Leišová et al. 2006; Nicolaisen et al. 2009; Yli-Mattila et al. 2008).

The objective of this study was to conduct microscopic observations and PCR assays of Fusarium pathogens infecting the grain of two winter wheat cultivars and to determine the effectiveness of the applied fungicide treatments.

\section{MATERIALS AND METHODS}

A two-factorial field experiment was performed in four replications in the Production and Experimental Station in Bałcyny during the growing seasons of 2005/2006 and 2006/2007. The experimental factors were two winter wheat cultivars: Zyta - a high grade wheat cultivar (A), and Nutka - a bread wheat cultivar (C), and fungicide treatments:

I. control (no fungicide treatment);

II. comprehensive fungicide treatment: Juwell TT 483 SE (epoxiconazole+kresoxim-methyl +fenpropimorph) - applied at stem elongation stages BBCH 33-35, and Swing Top 183 SC (dimoxystrobin+epoxiconazole) - applied at inflorescence emergence and heading stages BBCH 51-53.

Fungicides, dose rates and application dates were selected according to the recommendations of the Plant Protection Institute. The health status of wheat grain was evaluated under a microscope and by PCR after DNA isolation.

Mycological analyses of winter wheat grain were performed on 100 kernels in each replication. The grain of both wheat cultivars was surface disinfected with $70 \%$ ethanol and $1 \%$ sodium hypochlorite and placed on Petri plates containing solid PDA medium. After 14 days of incubation, fungal cultures were identified under a microscope based on the available reference standards (E11is, 1971; Gerlach and Nirenberg, 1982; Kw a śn a et al. 1991; W a t a n a be , 2002).

DNA was isolated by the method proposed by $\mathrm{K} \mathrm{ulik}$ et al. (2007). Ground wheat grains were placed in a porcelain mortar, treated with liquid nitrogen and homogenized. The homogenized material was transferred to $1.5 \mathrm{ml}$ Eppendorf tubes, incubated at $70^{\circ} \mathrm{C}$ for 40 minutes and centrifuged at $14000 \mathrm{rpm}$. The supernatant was loaded onto a minicolumn filled with silica and centrifuged. Silica-bound DNA was washed twice with $70 \%$ ethanol, rinsed in TE buffer and stored at $4^{\circ} \mathrm{C}$ until further analysis.

PCR analyses were carried out with the use of species-specific primers for Fusarium fungi isolated from winter wheat grain in the growing seasons of 2005/2006 and 2006/2007: Fusarium spp. P58SL 5'-
AGT ATT CTG GCG GGC ATG CCT GT-3', P28SL 5'-ACA AAT TAC AAC TCG GGC CCG AGA-3' (H u e et al. 1999); Fusarium avenaceum $\mathrm{FaR} 55^{\prime}$-CAA GCA TTG TCG CCA CTC TC-3', FaF 5'-GTT TGG CTC TAC CGG GAC TG-3' (D o o h a n et al. 1998); Fusarium culmorum Fc01F 5'-ATG GTG AAC TCG TCG TGG C-3', Fc01R 5'-CCC TTC TTA CGC CAA TCT TCT CG-5'(N ichols on et al. 1998); Fusarium graminearum Fg16NF 5'-ACA GAT GAC AAG ATT CAG GCA CA-3', Fg16NR 5'-TTC TTT GAC ATC TGT TCA ACC CA-3' (Nicholson et al. 1998); Fusarium poae Poa1 5'-CTT GGT AGG GGG GAC AGA CAC GC-3', Poa2 5'-CCA TTC CAC GCT CGA CAG ACC TG-3' (K ulik, 2008); Fusarium sporotrichioides FspITS2K 5'-CTT GGT GTT GGG ATC TGT GTG CAA-3' (K u lik in. 2004); P28SL 5'-ACA CAA CGG GCT ATA ACA CTC CCC-3' (H u e et al. 1999).

The PCR assay was carried out in an Eppendorf thermocycler (Mastercykler Gradient) on $25 \mu \mathrm{l}$ of the reaction mixture composed of: reaction buffer, $\mathrm{MgCl}_{2}$ magnesium ions $(2.5 \mathrm{mM})$, dNTPs free nucleotides $(200 \mu \mathrm{M}), 10 \mathrm{pM}$ of each primer, MasterAmpTM Tfl DNA Polymerase $(0.25 \mathrm{U})$ (Epicentre Biotechnologies, USA) and matrix DNA (5 $\mu \mathrm{l})$.

The reaction product was subjected to electrophoretic separation in a Sigma-Aldrich system in 1.5\% agarose gel with the addition of ethidium bromide. The size of PCR products was evaluated in a UV transilluminator (Fotodyne) by comparison with the Step Ladder 50bp molecular weight standard.

Real-time PCR was performed for quantitative DNA detection of Fusarium poae isolated from winter wheat grain. The reaction mixture had a volume of $25 \mu$, comprising: $12.5 \mu \mathrm{l}$ of TaqMan Universal PCR Master Mix (Applied Biosystems, USA), $10 \mathrm{pM}$ of TMpoaef 5'-GCT GAG GGT AAG CCG TCC TT3', $10 \mathrm{pM}$ of TMpoaer 5'-TCT GTC CCC CCT ACC AAG CT $-3^{\prime}$ and $10 \mathrm{pM}$ of $5^{\prime}$-ATT TCC CCA ACT TCG ACT CTC CGA GGA-3' (Y1i-Matilla et al. 2008) probe with 6-FAM (6-carboxyfluorescein) at the 5'-end and TAMRA (5-carboxytetramethylrhodamine) at the 3 '-end as the quencher, $4.5 \mu \mathrm{l}$ deoionized water and $5 \mu \mathrm{DNA}$. The following dilutions of standard reagents were used to make the standard curve: $25 \mathrm{pg}^{*} \mathrm{\mu l}^{-1}, 2.5^{*} \mathrm{pg} \times \mu^{-1}, 0.25^{*} \mathrm{pg} \times \mu \mathrm{l}^{-1}, 0.025^{*} \mathrm{pg} \times \mu \mathrm{l}^{-1}$, $0.0125 \mathrm{pg}^{*} \mathrm{ll}^{-1}$ in 2006 and $250 \mathrm{pg}^{*} \mu^{-1}, 25^{*} \mathrm{pg} \times \mu \mathrm{l}^{-1}$, $2.5^{*} \mathrm{pg} \times \mu \mathrm{l}^{-1}, 0.25^{*} \mathrm{pg} \times \mu \mathrm{l}^{-1}, 0.025^{*} \mathrm{pg} \times \mu \mathrm{l}^{-1}$ in 2007 (the quantity of DNA was determined in a Hoefer DynaQuant 200 fluorometer (Pharmacia, USA). A real-time PCR assay was carried out in a ABI Prism 7500 system (Applied Biosystems). The efficiency of real-time PCR was determined based on normalized transcript levels $(\mathrm{Ct})$. A standard curve was plotted against the logarithmic values of initial matrix DNA concen- 
trations. The efficiency of real-time PCR amplification $[E]$ was determined based on the following formula: $E=10^{(-1 / \text { slope })}-1$ (Pfaffl, 2001) (Fig. 1).

The results were processed in the Statistica v. 10.0 application (www.statsoft.com) with the use of Duncan's test $(\mathrm{p}=0.01)$. Standard deviation and ho- mogenous groups (A, B, C) identifying significant differences between means were determined (means denoted by the same letters did not differ significantly at $\mathrm{p}=0.01$ ). Pearson's linear correlation coefficient was calculated to determine the strength of relationships between variables.

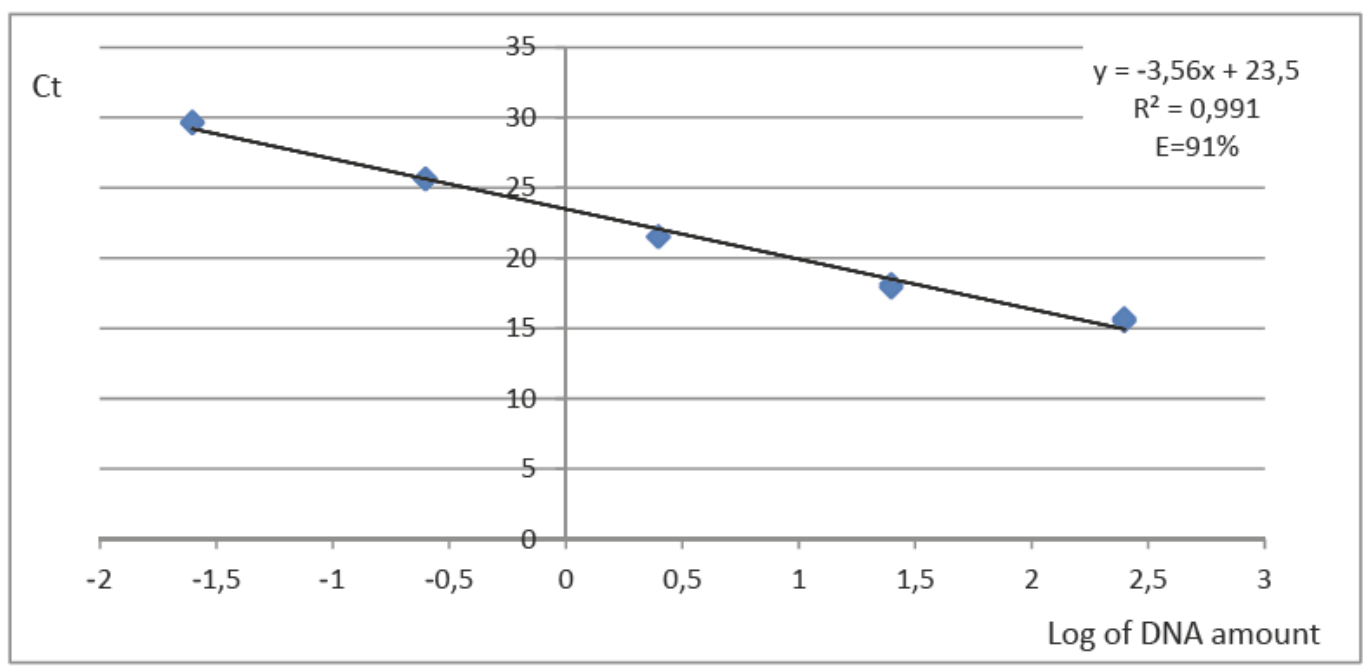

Fig. 1 Standard curve with 10-fold serial dilutions of $F$. poae DNA indicating the efficiency of real-time PCR assay.

\section{RESULTS}

The grain of winter wheat cultivars Nutka and Zyta was infected by fungi of the genus Fusarium in both years of the study (Table 1). The fungal species of the genus Fusarium identified by PCR were largely consistent with those observed in microscopic analysis. $F$. poae was identified by PCR with the use of specific primers (Poa1, Poa2) and in microscopic observations of fungal cultures. When universal primers (P58SL/ P28SL) and specific primers for $F$. graminearum (Fg16NF, Fg16NR) were applied, PCR proved to be more effective - the analyzed fungi were identified by genus-specific primers in three out of eight experimental treatments (2006-2007) and by species-specific primers in five treatments (Table 1). The primers Fc01F, Fc01R ( $F$. culmorum) and Faf, Far ( $F$. avenaceum) failed to identify the examined fungi, and microscopic evaluations produced more accurate results (Table 1).

Microscopic analysis revealed the presence of fungi of the genus Fusarium in all experimental treatments (Table 1). In both years of the study, Fusarium poae was the predominant and most abundant pathogen in the analyzed grain, and it was subjected to qPCR analysis. Fusarium culmorum and F. graminearum, fungal species which produce trichothecenes, were rarely observed. The analyzed grain was also colonized by other pathogenic species, mainly Drechslera biseptata and Bipolaris sorokiniana as well as Alternaria alternata which was the most abundant of all identified fungal species and genera in all treatments (Table 2).

The use of real-time PCR for the quantification of $F$. poae DNA revealed that Juwell TT 483 SE (epoxiconazole+kresoxim-methyl+fenpropimorph) and Swing Top 183 SC (dimoxystrobin+epoxiconazole) significantly reduced the amount of $F$. poae DNA in the grain of winter wheat cv. Zyta (Table 3). The above correlation was observed in the grain of winter wheat cv. Nutka in the second year of the experiment, whereas in the first year of the study the analyzed fungicides led to an insignificant increase in the amount of pathogenic DNA in comparison with the control (Table 3). Real-time PCR revealed a higher quantity of $F$. poae DNA in 2007, which suggests that the analyzed species is affected by weather conditions. In May and June 2007 , the average daily temperatures were determined at $13.7^{\circ} \mathrm{C}$ and $17.5^{\circ} \mathrm{C}$, respectively, and they were higher than the temperatures recorded in the respective periods of 2006 and than the long-term mean, which probably contributed to higher infection rates in 2007 (Fig. 2). The temperatures in May and June 2007 were higher, while precipitation levels were lower by 13.2 $\mathrm{mm}$ and $22.7 \mathrm{~mm}$ in comparison with the corresponding months of 2006 (Fig. 3).

In 2006 , significantly fewer $F$. poae cultures were isolated from wheat grain and smaller amounts of pathogenic DNA were observed. The number of isolated cultures increased in 2007, and an increase in the amount of pathogenic DNA was reported in a qPCR assay. 
Mathematical analysis revealed that the results of qPCR assays investigating winter wheat $\mathrm{cv}$. Zyta corresponded with the results of microscopic evaluations of pathogen cultures. A positive correlation $(\mathrm{R}=0.61)$ was observed between the amount of $F$. poae DNA and the number of $F$. poae colonies (Fig. 4a). No significant correlations were reported in winter wheat cv. Nutka (Fig. 4b).

The effect of $F$. poae on the yield and thousand grain weight (TGW) of winter wheat was also determined statistically (TGW data were presented by $\mathrm{J}$ a $\mathrm{r}$ m ołk ow i c z and O ls zew s ki, 2010). The studied wheat cultivars responded differently to the analyzed pathogen. Zyta, the more affected cultivar, was charac- terized by lower yield and lower TGW. The observed results validate the correlation coefficients between the amount of pathogenic DNA vs. yield $(\mathrm{R}=-0.76)$ (Fig. 5a) and TGW (R=-0.83) (Fig. 5b), and between the number of isolated cultures vs. yield $(\mathrm{R}=-0.68)$ (Fig. 6a) and TGW (R=-0.41) (Fig. 6b).

Cv. Nutka was less infected by $F$. poae, and it was characterized by a smaller reduction in yield and TGW than cv. Zyta, as demonstrated by the correlation coefficients between the amount of pathogenic DNA vs. yield ( $\mathrm{R}=-0.24)$ (Fig. 5c) and TGW ( $\mathrm{R}=-0.32)$ (Fig. 5d), and between the number of isolated cultures vs. yield $(\mathrm{R}=-0.04)$ (Fig. 6c) and TGW (R=-0.26) (Fig. 6d).

Table 1

Fungi of the genus Fusarium isolated from winter wheat grain and identified with PCR assay in 2006-2007

\begin{tabular}{|c|c|c|c|c|c|}
\hline \multirow{2}{*}{ Startery Primers } & \multirow{2}{*}{ Fungal genus/species } & \multicolumn{2}{|c|}{ Nutka } & \multicolumn{2}{|c|}{ Zyta } \\
\hline & & control & fungicide & control & fungicide \\
\hline \multicolumn{6}{|c|}{$(2006)-1$ st year of study } \\
\hline P58SL, P28SL (Hu e et al. 1999) & Fusarium spp. & $+* / 2 * *$ & $+/ 2$ & $+/ 4$ & $+/ 0$ \\
\hline Faf, Far (D o o han et al. 1998) & Fusarium avenaceum (Fr.) Sacc. & $-/ 2$ & $-/ 0$ & $-/ 1$ & $-/ 2$ \\
\hline $\begin{array}{l}\text { Fc01F, Fc01R } \\
\text { (Nichols on et al. 1998) }\end{array}$ & Fusarium culmorum (W.G. Sm.) Sacc. & $-/ 0$ & $-/ 0$ & $-/ 1$ & $-/ 0$ \\
\hline $\begin{array}{l}\text { Fg16NF, Fg16NR } \\
\text { (Nichols on et al. 1998) }\end{array}$ & Fusarium graminearum Schwabe & $+/ 0$ & $+/ 0$ & $-/ 0$ & $+/ 2$ \\
\hline Poa1, Poa2 (Kulik, 2008); & Fusarium poae (Peck) Wollenw. & $+/ 1$ & $+/ 6$ & $+/ 9$ & $+/ 4$ \\
\hline $\begin{array}{l}\text { FspITS2K (K u lik, 2008), } \\
\text { P28SL (Hu e et al. 1999) }\end{array}$ & Fusarium sporotrichioides Sherb. & $+/ 0$ & $+/ 0$ & $+/ 0$ & $+/ 0$ \\
\hline- & Fusarium dimerum Penz. & 0 & 0 & 2 & 0 \\
\hline- & Fusarium equiseti (Corda) Sacc. & 1 & 0 & 1 & 0 \\
\hline- & Fusarium oxysporum Schltdl. & 2 & 1 & 1 & 1 \\
\hline Total & & 8 & 9 & 20 & 9 \\
\hline \multicolumn{6}{|c|}{$(2007)-2$ nd year of study } \\
\hline P58SL, P28SL (Hue et al. 1999) & Fusarium spp. & $+/ 1$ & $+/ 1$ & $+/ 0$ & $+/ 0$ \\
\hline Faf, Far (D o o han et al. 1998) & Fusarium avenaceum (Fr.) Sacc. & $+/ 5$ & $+/ 5$ & $+/ 7$ & $+/ 7$ \\
\hline $\begin{array}{l}\text { Fc01F, Fc01R } \\
\text { (Nichols on et al. 1998) }\end{array}$ & Fusarium culmorum (W.G. Sm.) Sacc. & $-/ 0$ & $-/ 3$ & $-/ 0$ & $+/ 1$ \\
\hline $\begin{array}{l}\text { Fg16NF, Fg16NR } \\
\text { (Nichols on et al. 1998) }\end{array}$ & Fusarium graminearum Schwabe & $+/ 1$ & $+/ 0$ & $+/ 0$ & $+/ 0$ \\
\hline Poa1, Poa2 (Ku lik, 2008) & Fusarium poae (Peck) Wollenw. & $+/ 8$ & $+/ 12$ & $+/ 26$ & $+/ 18$ \\
\hline $\begin{array}{l}\text { FspITS2K (Kulik, 2004); } \\
\text { P28SL (Hu e et al. 1999) }\end{array}$ & Fusarium sporotrichioides Sherb. & $+/ 1$ & $+/ 3$ & $+/ 5$ & $+/ 7$ \\
\hline- & Fusarium equiseti (Corda) Sacc. & 0 & 0 & 3 & 0 \\
\hline- & Fusarium tricinctum (Corda) Sacc. & 3 & 3 & 6 & 8 \\
\hline- & Fusarium verticillioides (Sacc.) Nirenberg & 1 & 0 & 0 & 1 \\
\hline Total & & 19 & 27 & 47 & 42 \\
\hline
\end{tabular}

*-/+ - negative / positive (classic PCR)

$* *$ - number of isolates 
Table 2

Other fungi isolated from winter wheat grain in 2006-2007

\begin{tabular}{|c|c|c|c|c|}
\hline \multirow{2}{*}{ Fungal genus/species } & \multicolumn{2}{|c|}{ Nutka } & \multicolumn{2}{|c|}{ Zyta } \\
\hline & control & fungicide & control & fungicide \\
\hline \multicolumn{5}{|c|}{ (2006) - 1st year of study } \\
\hline Alternaria alternata (Fr.) Keissler & 328 & 299 & 243 & 262 \\
\hline Aureobasidium pullulans (De Bary) Arnaud & & 2 & 2 & 2 \\
\hline Bipolaris sorokiniana (Sacc.) Shoemaker & 5 & 8 & 4 & 5 \\
\hline Botrytis cinerea Pers. & 3 & 1 & 0 & 0 \\
\hline Cladosporium cladospirioides (Fries.) de Vries & 1 & 3 & 11 & 2 \\
\hline Drechslera biseptata (Sacc. \& Roum.) M.J. Richardson \& E.M. Fraser & 11 & 10 & 4 & 5 \\
\hline Epicoccum nigrum Link & 26 & 28 & 8 & 12 \\
\hline Oidiodendron griseum Robak & 0 & 0 & 0 & 1 \\
\hline Papularia spp. & 1 & 1 & 3 & 2 \\
\hline Penicillium spp. & 3 & & 1 & 2 \\
\hline Rhizoctonia spp & 1 & 1 & 0 & 1 \\
\hline Stemphylium spp. & 0 & 0 & 0 & 2 \\
\hline Non-sporulating colonies & 3 & 1 & 6 & 3 \\
\hline Total & 382 & 354 & 282 & 299 \\
\hline \multicolumn{5}{|c|}{ (2007) - 2nd year of study } \\
\hline Alternaria alternata (Fr.) Keissler & 268 & 296 & 264 & 252 \\
\hline Aureobasidium pullulans (De Bary) Arnaud & 5 & 0 & 0 & 0 \\
\hline Bipolaris sorokiniana (Sacc.) Shoemaker & 40 & 37 & 27 & 29 \\
\hline Botrytis cinerea Pers. & 1 & 1 & 0 & 2 \\
\hline Cladosporium cladospirioides (Fries.) de Vries & 13 & 2 & 9 & 13 \\
\hline Drechslera biseptata (Sacc ex Roum) Richardson et Fraser & 16 & 2 & 13 & 4 \\
\hline Epicoccum nigrum Link & 29 & 35 & 25 & 43 \\
\hline Nigropora spp. & 1 & 1 & 1 & \\
\hline Papularia spp. & 2 & 0 & 3 & 2 \\
\hline Penicillium spp. & 3 & 0 & 0 & 1 \\
\hline Phoma medicaginis Malbr. \& Roum. & 0 & 0 & 1 & 0 \\
\hline Stemphylium spp. & 1 & 1 & 0 & 0 \\
\hline Total & 379 & 375 & 343 & 346 \\
\hline
\end{tabular}

Table 3

Amount of $F$. poae DNA in winter wheat grain treated with fungicides Juwell TT $483 \mathrm{SE}$ and Swing Top 183 SC in 2006-2007 (pg of DNA)

\begin{tabular}{|c|c|c|c|c|c|}
\hline Year & Cultivar & Treatments & Amount of DNA [pg] & $\mathrm{SD}$ & Homogenous groups \\
\hline \multirow{4}{*}{2006} & \multirow{2}{*}{ Nutka } & control & 0,0032 & 0,0002 & $\mathrm{BC}$ \\
\hline & & fungicide & 0,0041 & 0,0002 & $\mathrm{~B}$ \\
\hline & \multirow{2}{*}{ Zyta } & control & 0,0090 & 0,0088 & A \\
\hline & & fungicide & 0,0025 & 0,0019 & $\mathrm{C}$ \\
\hline \multirow{4}{*}{2007} & \multirow{2}{*}{ Nutka } & control & 0,0062 & 0,0011 & $\mathrm{~B}$ \\
\hline & & fungicide & 0,0029 & 0,0003 & $\mathrm{C}$ \\
\hline & \multirow{2}{*}{ Zyta } & control & 0,0237 & 0,0003 & A \\
\hline & & fungicide & 0,0055 & 0,0013 & $\mathrm{~B}$ \\
\hline
\end{tabular}

$\mathrm{p}=0,01$ 


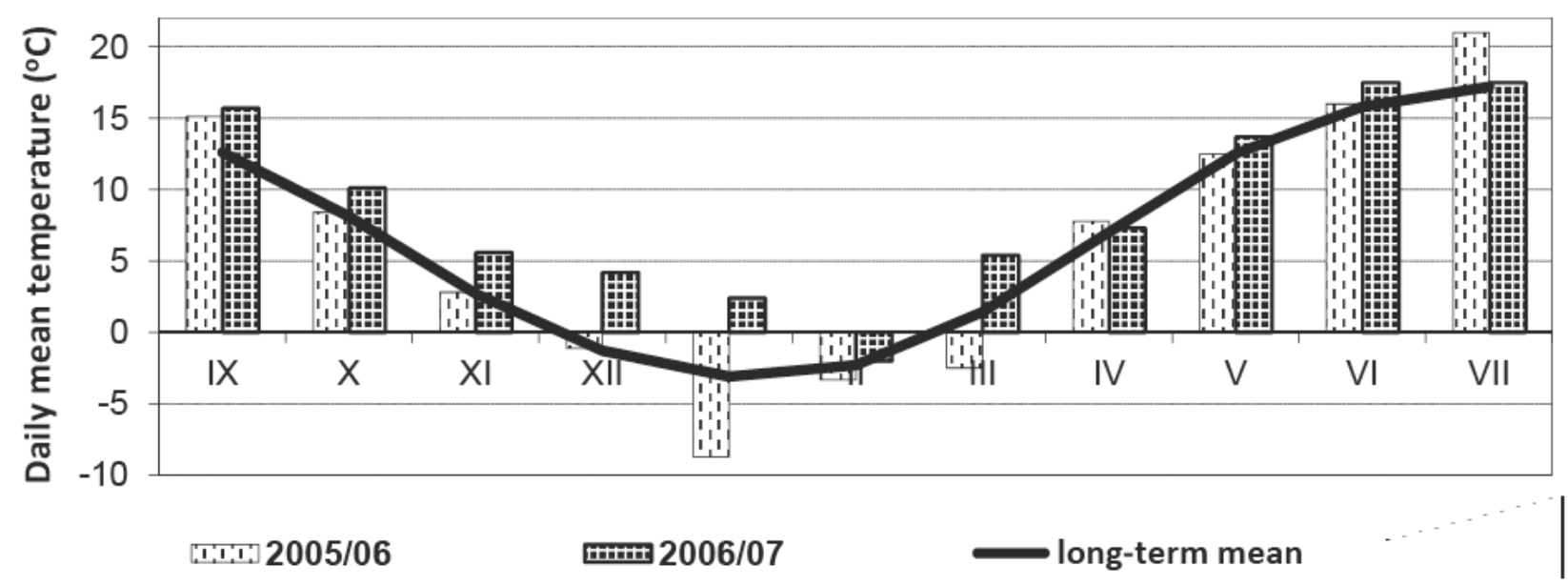

Fig. 2 Mean daily air temperature during the growing season of winter wheat in 2006-2007 compared with the long-term mean (1961-2000).

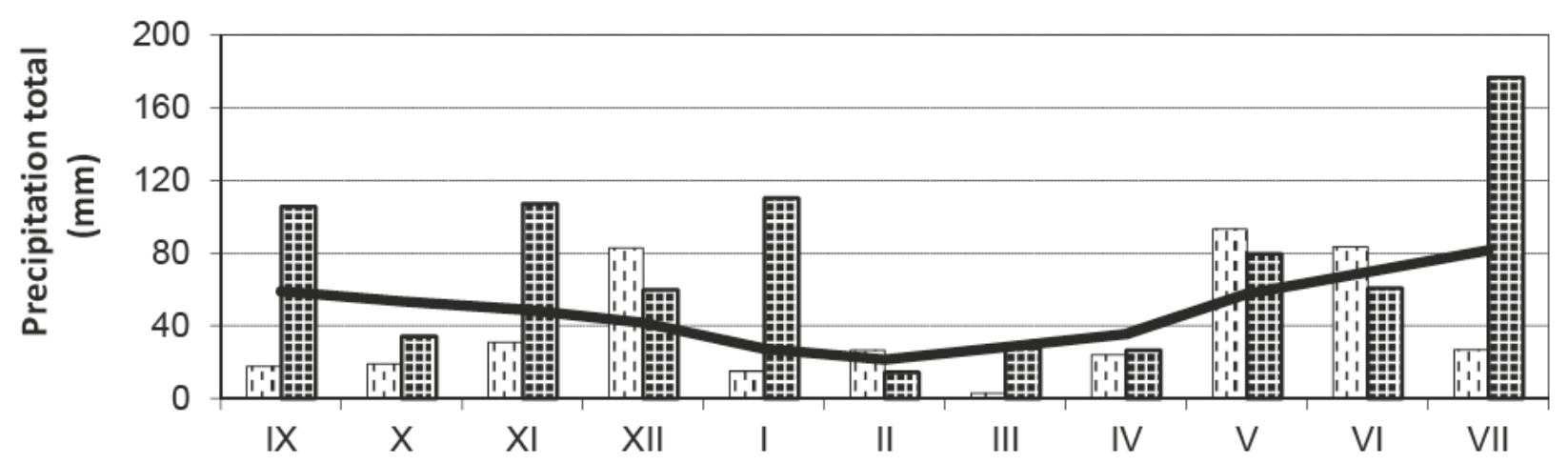

2005/06

冊覀 2006/07

long-term mean

Fig. 3 Mean total precipitation during the growing season of winter wheat in 2003-2007 compared with the long-term mean (1961-2000).

A

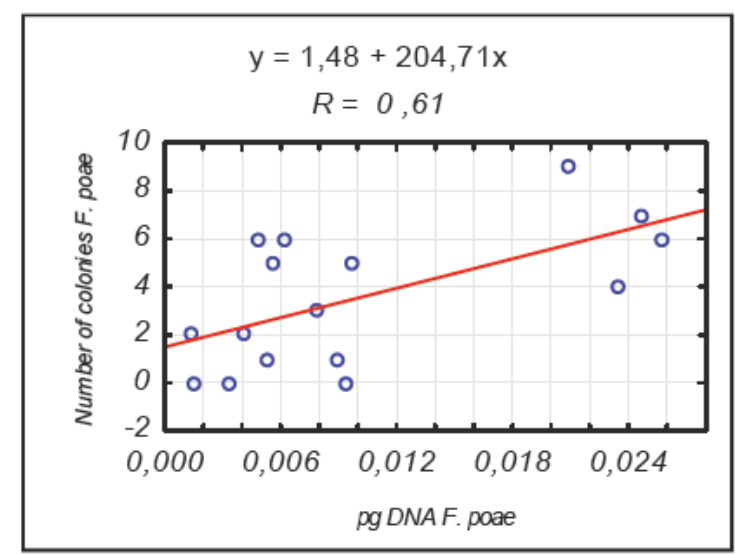

B

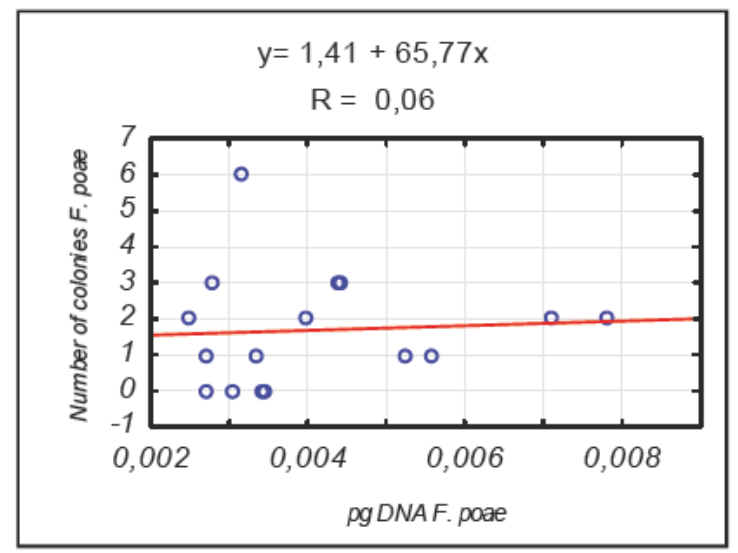

Fig. 4 Linear correlation between the number of $F$. poae colonies isolated from winter wheat grain and amount of DNA [A] - Zyta, [B] - Nutka. 
A

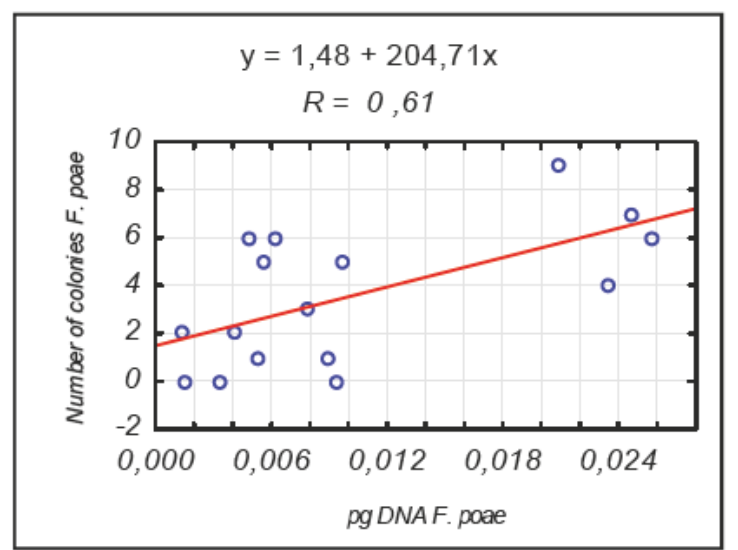

B

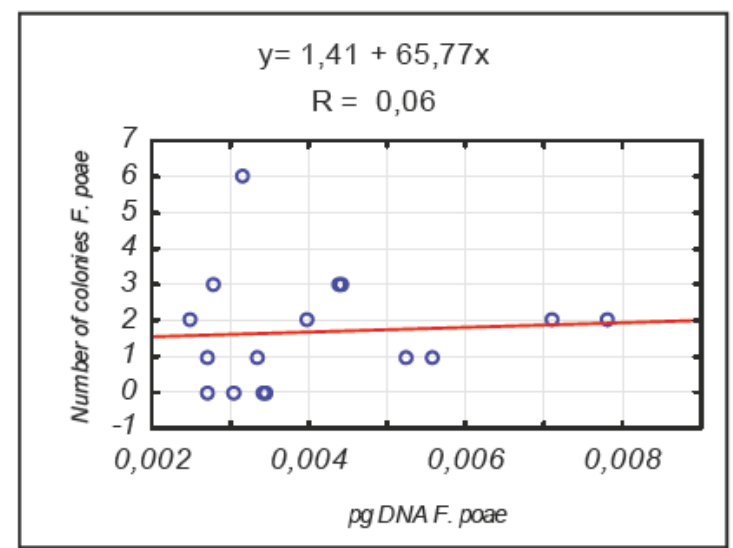

Fig. 5 Linear correlation between amount of $F$. poae DNA and yield; thousand grain weight (MTZ) of winter wheat cultivars $[\mathrm{A}, \mathrm{B}]-$ Zyta, $[\mathrm{C}, \mathrm{D}]-$ Nutka.

A

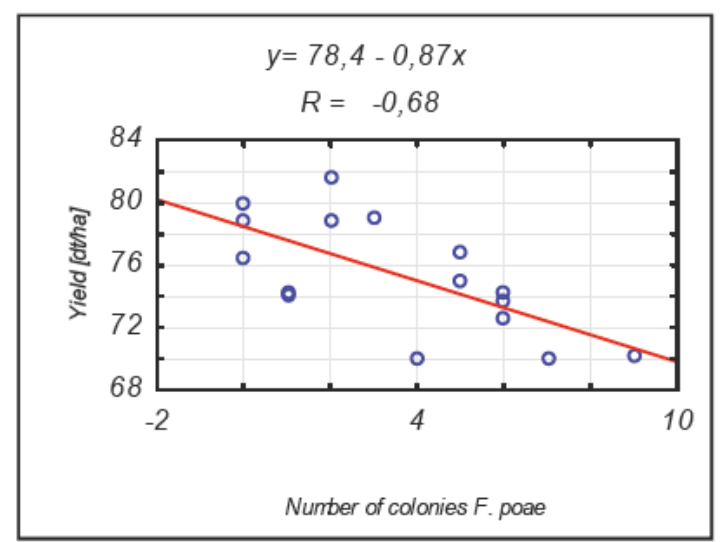

B

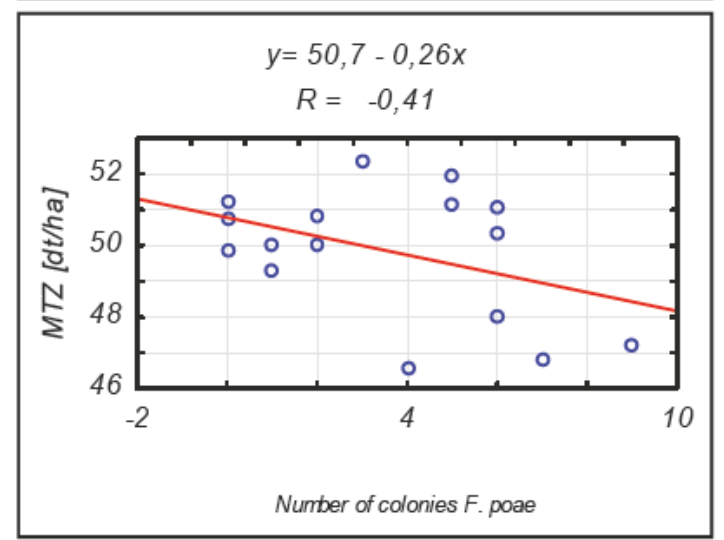

C

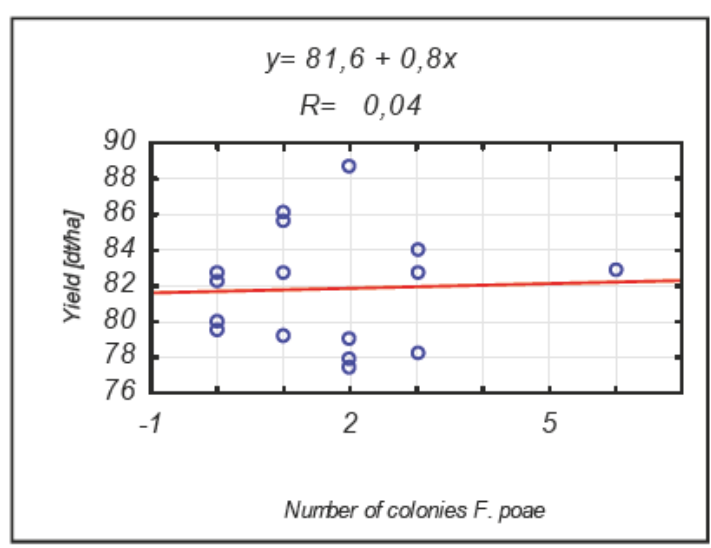

D

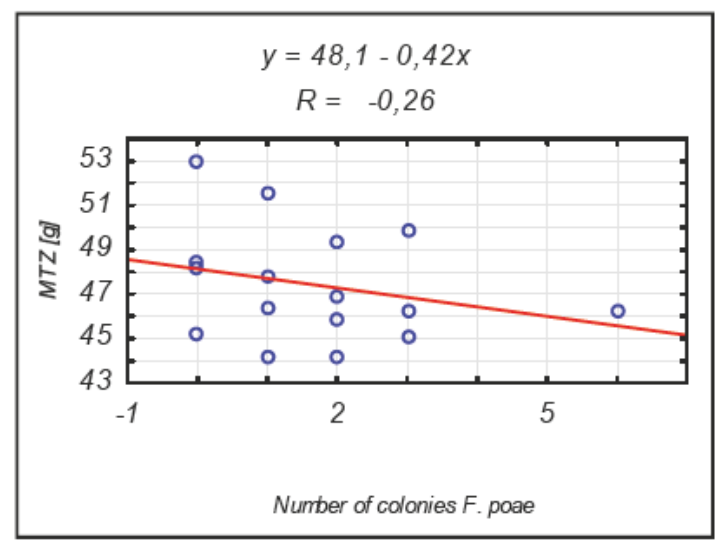

Fig. 6 Linear correlation between the number of $F$. poae colonies and yield; thousand grain weight (MTZ) of winter wheat cultivars $[A, B]-Z y t a,[C, D]-$ Nutka.

\section{DISCUSSION}

The grain of winter wheat cv. Nutka and Zyta was infected by fungi of the genus Fusarium. The applied pair of universal primers (P58SL/P28SL) generated a product with the length of $339 \mathrm{bp}$ in all treatments and all years of the study. Other primer sets also supported the identification of selected species in the experimental treatments. Similar results were reported by Pszczółkowska (2008) who investigated the health status of wheat grain treated with various fungicides and confirmed the usefulness of molecular diagnostic methods.

PCR results were largely consistent with microscopic observations of the analyzed fungi. However, the species-specific primers for the detection of $F$. culmorum $(\mathrm{Fc} 01 \mathrm{~F}, \mathrm{Fc} 01 \mathrm{R}$ ) and $F$. avenaceum (Faf, Far) were less effective than the microscopic method. 
The above could be attributed to small quantities of pathogenic fungi in wheat grain as well as difficulties in DNA isolation. According to Q u a rt a et al. (2006), the PCR detection threshold for primers amplifying Tri gene fragments was $4 \mathrm{pg}$ of DNA, which corresponds to approximately 88 fungal spores of the genus Fusarium. B r e n n a n et al. (2007) isolated $F$. poae characterized by similar aggressiveness to $F$. culmorum and $F$. graminearum, but the evaluated grain contained less $F$. poae DNA because this species colonizes glumes rather than deeper layers of the grain.

The results of microscopic observations and qPCR assays confirmed that $F$. poae was the predominant pathogen of the genus Fusarium in both years of the study. The predominance of $F$. poae in the species composition of fungal communities colonizing cereal crops in various regions of Europe was also observed by other authors (B ot t a li c o and Perrone, 2002; Łukanowski and Sadowski, 2002; Kieca$\mathrm{n}$ a et al. 2005; Pszczółkowska, 2008; Kulik, 2008,; Y li - M attila et al. 2008; X u et al. 2005).

Fungicidal treatments applied in this experiment failed to fully eliminate fungal pathogens of the genus Fusarium. In both years of the study, the fungicides decreased the number of $F$. poae colonies and isolates of the genus Fusarium in winter wheat cv. Zyta. A reverse correlation was observed in wheat cv. Nutka. The results of real-time PCR revealed a significant decrease in the amount of $F$. poae DNA in winter wheat cv. Zyta in both experimental years. In wheat cv. Nutka, the above correlation was noted only in the second year of the study. Our results are consistent with the findings of other authors who demonstrated that triazole-based fungicides were most effective in controlling FHB (Mesterhazy et al. 2003; P a u et al. 2008; S impson et al. 2001). In a study by Edwards and Godley (2010), the application of prothioconazole significantly alleviated FHB symptoms and lowered DON concentrations in winter wheat grain. Chala et al. (2003) demonstrated that fungicides significantly reduced mycotoxin concentrations and increased yield. Mesterhazy et al. (2003) observed that wheat plants treated with various fungicides were characterized by lower levels of Fusarium spp. infection, lower yield loss and reduced DON concentrations in comparison with the control. In the above study, the best results were reported for tebuconazole. In a field experiment carried out by $\mathrm{S}$ i $\mathrm{m} \mathrm{p} \mathrm{s} \mathrm{o} \mathrm{n}$ et al. (2001), the application of azoxystrobin led to changes in pathogen populations colonizing wheat spikes. The population of Microdochium nivale was reduced, but a higher incidence of infections caused by Fusarium spp. was observed. Tebuconazole was significantly more effective in eliminating Fusarium spp. than Microdochium spp. In the work of P s z c z ó łk o w s ka
(2008), a higher incidence of infections caused by Fusarium spp. was observed in wheat plots where Amistar 250 SC (azoxystrobin) was applied as the second fungicide treatment.

Š i p et al. (2010) investigated the effectiveness of the Swing Top fungicide in reducing $F$. graminearum populations, DON concentrations and yield loss in wheat plants artificially inoculated with this fungal species. The analyzed fungicide reduced DON concentrations by $49.5 \%$ and minimized yield loss by $63.9 \%$ on average, but the observed results varied throughout different years and experimental sites. The combined effect of cultivar resistance and fungicide treatment was responsible for an $86.5 \%$ decrease in DON concentrations and a $95.4 \%$ reduction in yield loss.

In this study, the prevalence of wheat grain infections caused by $F$. poae was affected by weather conditions. Higher quantities of $F$. poae DNA were reported in 2007 which was characterized by higher temperatures and lower precipitation levels in May and June in comparison with the respective periods of the previous year and the long-term mean. In a study by $\mathrm{W}$ a g a $\mathrm{ch}$ a et al. (2012), higher temperatures contributed to the germination of $F$. poae spores $-10 \%$ of spores incubated at $22^{\circ} \mathrm{C}$ germinated after four hours, and $50 \%$ of spores after six hours. Spore germination was inhibited at $10^{\circ} \mathrm{C}$ when the percentage of germinated spores reached $10 \%$ after 10 hours and exceeded $30 \%$ after 12 hours of incubation (W a g a c h a et al. 2012).

The results of other research studies indicate that higher temperatures contribute to the proliferation of $F$. graminearum, whereas $F$. culmorum, $F$. poae and $F$. avenaceum thrive in colder climates (Doohan et al. 2003). According to R ohácik and $\mathrm{Hudec}$ (2005), in colder regions the prevalence of $F$. poae infections is higher, but the concentrations of the analyzed pathogen in grain tend to be lower. $\mathrm{K} \mathrm{r}$ is s et al. (2012) observed a negative correlation between precipitation levels and $F$. poae concentrations in winter wheat grain, which implies that the examined pathogen thrives in periods characterized by lower rainfall. In our study, the lower levels of fungal infection in 2006 could be attributed to weather conditions which were less conducive to the growth of $F$. poae.

In winter wheat 'Zyta', a positive correlation was noted between the number of isolated $F$. poae colonies and the amount of pathogenic DNA in grain. The higher incidence of $F$. poae infections in Zyta decreased yield and TGW, which was validated by the results of mathematical analysis. Similar results were reported by Brennan et al. (2007) who observed a correlation between the DNA amount and TGW values in various wheat cultivars - the decrease in TGW values of the examined cultivars ranged from $3 \%$ to more than $20 \%$ in correlation analysis. 
In our study, winter wheat was also colonized by other species of pathogenic fungi. Bipolaris sorokiniana and Drechslera biseptata were relatively abundant, whereas Botrytis cinerea and fungi of the genus Rhizoctonia were less frequently isolated. A much higher number of pathogenic species was observed in the second year of the experiment which was characterized by an abundance of Bipolaris sorokiniana isolates; they accounted for approximately $10 \%$ of all fungal taxa isolated from the grain of winter wheat cv. Nutka in 2007 and had an estimated $8 \%$ share in the taxa isolated from the grain of winter wheat $\mathrm{cv}$. Zyta. $B$. sorokiniana causes spot blotch, common root rot and cereal grain infections ( $\mathrm{K} \mathrm{u} \mathrm{m}$ a r et al. 2002). The species contributes to a significant loss of spring grain crops, and it reduces the germination capacity of seeds (W i e wi ó ra , 2006). The source of infection is contaminated seed material, which is why seed dressing is the most effective method of controlling the spread of B. sorokiniana (A c h a r y a et al. 2011).

The fungicides used in this experiment did not reduce the abundance of $B$. sorokiniana in winter wheat. In the work of Baturo (2008), the discussed fungal species had a more damaging effect on organically-grown barley which was not chemically protected. According to D u veille r et al. (2005), triazole-based fungicides - tebuconazole, propiconazole and epoxiconazole - were the most effective in controlling the growth of $B$. sorokiniana.

In this experiment, we studied naturally infected winter wheat plants, which contributed to a better understanding of the relationships between host plants and pathogens. The observed results are, however, not exhaustive, and further work is needed to investigate the pathogenesis of $F$. poae and its susceptibility to weather conditions.

\section{Author's contributions}

The following declarations about authors' contributions to the research have been made: designing the experiments: AP, JO; field research: JO, JJ; laboratory research: AP, AO, JJ; determination of the fungal pathogens: AP, AO; data analyses: AO, AP; writing the manuscript: AP, AO, JO; drawings: AO.

\section{Acknowledgements}

Research supported by the Ministry of Science and Higher Education of Poland as the part of statutory activities of Department of Diagnostics and Plant Pathophysiology, University of Warmia and Mazury, Olsztyn, Poland

\section{REFERENCES}

Acharya K., Dutta A.K., Pradhan P. 2011. Bipolaris sorokiniana (Sacc.) Shoem.: The most destructive wheat fungal pathogen in the warmer areas. AJCS 5(9): 1064-1071.

B at u ro A. 2008. Share of Bipolaris sorokiniana in the infection of spring barley cultivars cultivated in various regions of Poland. Prog. Plant Protection, 48(1): 163-167.

Bottalico A., Perrone G. 2002. Toxigenic Fusarium species and mycotoxins associated with head blight in small-grain cereals in Europe. Eur. J. Plant Pathol. 108: 611-624.

Brennan J.M., Leonard G., Fagan B., Cooke B.M., Ritieni A., Ferracane R., Nicholson P., Simpson D., Thomsett M., Doohan F.M. 2007. Comparison of commercial European wheat cultivars to Fusarium infection of head and seedling tissue. Plant Pathology, 56: 55-64. http://dx.doi.org/ 10.1111/j.1365-3059.2006.01458.x

Chala A., Weinert J., Wolf G.A. 2003. An integrated approach to the evaluation of the efficacy of fungicides against Fusarium culmorum, the cause of head blight of wheat. J. Phytopathology; 151: 673-678. http://dx.doi.org/10.1046/j.1439-0434.2003.00787.x

Doohan F.M., Brennan J., Cooke B.M. 2003. Influence of climatic factors on Fusarium species pathogenic to cereals. Eur. J. Plant Pathol. 109: 755-768.

Doohan F.M., Parry D.W., Jenkinson P., Nichols on P. 1998. The use of species - specific PCR based assays to analyse Fusarium ear blight of wheat. Plant Pathology, 47: 197-205. http://dx.doi.org/10. 1046/j.1365-3059.1998.00218.x

Duveiller E., Kandel Y.R., Sharma R.C., Shrestha S.M. 2005. Epidemiology of foliar blights (spot blotch and tan spot) of wheat in the plains bordering the Himalayas. Phytopathol. 95(3): 248-256. http://dx.doi.org/10.1094/PHYTO-95-0248

Edwards S.G. Godley N.P. 2010. Reduction of Fusarium head blight and deoxynivalenol in wheat with early fungicide applications of prothioconazole. Food Addit. Contam. 27(5): 629-35. http://dx.doi. org/10.1080/19440040903515942

E11 is M.B. 1971. Dematiaceous Hyphomycetes. Commonwealth Mycological Institute. Key, Surrey, England, 608.

Fischer R.A. 1985. Number of kernels in wheat crops and the influence of solar radiation and temperature. J. Agric. Sci. Camb. 105:447-461. http://dx.doi.org/ $10.1017 /$ S0021859600056495

Gerlach W., Nirenberg H. 1982. The genus Fusarium - a pictorial atlas. Berlin-Dahlem. 406.

Goliński P., Waśkiewicz A., Wiśniewska H., Kiecana I., Mielniczuk E., Gromadzka K., Kostecki M., Bocianowski J., Rymaniak E. 2010. Reaction of winter wheat (Triticum aestivum L.) cultivars to infection with Fusarium spp.: mycotoxin contamination in grain and chaff. Food Add 
Contam, 27 (6): 1015-1024. http://dx.doi.org/10.1080/ 19440041003702208

Hue F.-X., Huerre M., Rouffault M. A., Bievre C. 1999. Specific Detection of Fusarium Species in Blood and Tissues by PCR Technique. J. Clin. Microbiol. 37(8): 2434-2438.

Jarmołkowicz J.K., Olszewski J.2010. Gas exchange parameters in leaves and ears of winter wheat Tricitum aestivum L. and its productivity under fungicide control conditions. Acta Agrobot. 63(2): 135-147.

Kiecana I., Mielniczuk E., Perkowski J., Goliński P. 2005. Porażenie wiech przez Fusarium poae (Peck) Wollenw. oraz zawartość mikotoksyn w ziarnie owsa. / Infection of panicles with Fusarium poae (Peck) Wollenw. and mycotoxin content in oat grain.]. Acta Agrobot. 58, 91-102. (in Polish)

Kiecana I., Cegiełko M., Mielniczuk E., Perkowski J. 2012. The occurrence of Fusarium poae (Peck) Wollenw. on oat (Avena sativa L.) panicles and its harmfulness. Acta Agrobot. 65(4): 169-178. http://dx.doi.org/10.5586/aa.2012.035.

Koncz Z.S., Magyar D., Naár Z., Kiss A., Szécsi Á. 2008. PCR-Based Assays for the Identification of Fusarium spp. Originating from Wheat Grain. Cer Res Comm.; 36(4):631-636. http://dx.doi.org/ 10.1556/CRC.36.2008.4.12

Kriss A.B., Paul P.A. , Xu X., Nicholson P., Doohan F. M., Hornok L., Rietini A., Edwards S. G., Madden L.V. 2012. Quantification of the relationship between the environment and Fusarium head blight, Fusarium pathogen density, and mycotoxins in winter wheat in Europe. Eur. J. Plant Pathol. 133:975-993. http://dx.doi.org/10.1007/s10658-01 2-9968-6

Kryczyński S. 2002. Podstawy fitopatologii. Fundacja Rozwój SGGW, Warszawa: 264. (in Polish).

Kulik T. 2008. Development of duplex PCR assay for the simultaneous detection of F. poae and F. sporotrichioides from wheat. J. Plant Pathol. 90(3): 441-447.

Kulik T., Fordoński G., Pszczółkowska A., Płodzień K. Łapiński M. 2004. Development of PCR assay based on ITS2 rDNA polymorphism for the detection and differentiation of Fusarium sporotrichioides. FEMS Microbiology Letters. 239: 181-186. http://dx.doi.org/10.1016/j.femsle.2004.08.037

Kulik T., Pszczółkowska A., Fordoński G., Olszewski J. 2007. PCR approach based on the esyn1 gene for the detection of potential enniatin - producing Fusarium species. Int. J. Food Microbiol. 116, 319-324. http://dx.doi.org/10.1016/j.ijfoodmicro.2007.02.003

Kulik T., Jestoi M., Okorski A. 2011. Development of TaqMan assays fort he quantitative detection of Fusarium avenaceum/Fusarium tritinctum and Fusarium poae esyn1 genotypes from cereal grain. FEMS Microbiology Letters. 314: 49-56. http://dx.doi.org/ 10.1111/j.1574-6968.2010.02145.x
Kumar J., P. Schafer R. Huckelhoven G. Langen H. Baltruschat E., Stein N., Subramanian K.H. Kogel J., Nagarajan S. 2002. Bipolaris sorokiniana, a cereal pathogen of global concern: cytological and molecular approaches towards better control. Mol. Plant Pathol. 3(4): 185-195. http://dx. doi.org/10.1046/j.1364-3703.2002.00120.x

Kwaśna H., Chełkowski J., Zajkowski P. 1991. Fungi (Mycota). XXII. PAN, Warszawa-Krakow. 152.

Kwaśna H., Bateman G.L. 2009. Microbial communities in roots of Pinus sylvestris seedlings with damping-off symptoms in two forest nurseries as determined by ITS1/2 rDNA sequencing. Forest Pathology, 39: 239-248. http://dx.doi.org/10.1111/j.1439-0329.2008.00583.x

Leišova L., Kučera L., Chrpova J., Sykorova S., Šip V., Ovesna J. 2006. Quantification of Fusarium culmorum in wheat and barley tissues using real-time PCR in comparison with DON content. J. Phytopathol. 154: 603-611. http://dx.doi.org/10.1111/j.1439-0434. 2006.01154.x

Leslie J.F., Summerell B.A. 2006. The Fusarium Laboratory Manual. Blackwell, Oxford, UK.

Łukanowski A., Sadowski Cz. 2002. Occurrence of Fusarium on grain and heads of winter wheat cultivated in organic, integrated, conventional systems and monoculture. J. Appl. Genet. 43A: 103-110.

Mesterhazy A., Bartok T., Lamper C. 2003. Influence of wheat cultivar, species of Fusarium, and isolate aggressiveness on the efficacy of fungicides for control of Fusarium Head Blight. Plant Disease, 87(9): 11071115. http://dx.doi.org/10.1094/PDIS.2003.87.9.1107

Mulé G., Gonzalez-Jaén M.T., Hornok L., Nicholson P., Waalwijk C. 2005. Advances in molecular diagnosis of toxigenic Fusarium species. Food Add. Contam. 22: 316-323. http://dx.doi.org/ 10.1080/02652030500058296

Nicholson P., Simpson D. R., Weston G., Rezanoor H. N., Lees A. K., Parry D. W., Joyce D. 1998. Detection and quantification of $\mathrm{Fu}-$ sarium culmorum and Fusarium graminearum in cereals using PCR assays. Physiol. Mol. Plant Pathol.' 53: 17-37.

Nicholson P., Chandler E., Draeger R.C., Gosman N.E., Simpson D.R., Thomsett M., Wils on A.H. 2003. Molecular tools to study epidemiology and toxicology of fusarium head blight of cereals. Eur. J. Plant Pathol. 109: 691-703.

Nicolaisen M., Suproniene S., Nielsen L.K., Lazzaro I., Spliid N.H., Justesen A.F. 2009. Real-time PCR for quantification of eleven individual Fusarium species in cereals. J. Microbiol. Methods, 76: 234-240. http://dx.doi.org/10.1016/j.mimet. 2008.10.016

Paul P.A., McMullen M.P., Hershman D.E., Madden L.V. 2008. Meta-analysis of the effects of triazole-based fungicides on wheat yield and test weight 
as influenced by Fusarium Head Blight intensity. Phytopathology. 100(2): 160-171. http://dx.doi.org/10.1094/ PHYTO-100-2-0160

Pfaffl M.W. 2001. A new mathematical model for relative quantification in real-time RT-PCR. Nucleic Acids Res. 29(9): e45.

Pląskowska E., Chrzanowska-Drożdż B. 2009. The health status of winter durum wheat grain in relation to fungicide treatment. Phytopathologia, 54: 23-32.

Pszczółkowska A. 2008. Diagnostyka patogenów grzybowych metodą PCR i tradycyjną oraz produktywność pszenicy ozimej (Triticum aestivum L.) w warunkach zróżnicowanej ochrony fungicydowej. Rozprawy i monografie, 140, UWM Olsztyn

Quarta A., Mita G., Haidukowski M., Logrieco A., Mulč G., Visconti A.2006.MultiplexPCR assay for the identification of nivalenol, 3- and 15-acetyl-deoxynivalenol chemotypes in Fusarium. FEMS Microbiology Letters. 259: 7-13. http://dx.doi.org/10. 1111/j.1574-6968.2006.00235.x

Rohácik T., Hudec K., 2005. Influence of agro-environmental factors on Fusarium infestation and population structure in wheat kernels. Ann. Agric. Environ Med. 12: $39-45$.

Scheider N., Guo J.-R., Verreet J.-A, Beyer M. 2009. Assessing the intensity of Fusarium-damage in wheat: A comparison of selected disease parameters during disease development and the role of fungicides. J. Plant Dis. Protec. 116 (3), 118-123.

Schilling A.G., Möller E.M., Geiger H.H.1996. Polymerase chain reaction - based assays for species-specific detection of Fusarium culmorum, F. graminearum and F. avenaceum. Phytopathology, 86(5): $515-522$.

Simpson D.R., Weston G.E., Turner J.A., Jennings P., Nicholson P. 2001. Differential control of head blight pathogens of wheat by fungicides and consequences for mycotoxin contamination of grain. Eur. J. Plant Pathol. 107: 421-431.

Šip V., Chrpova J., Veškrna O., Bobkova L. 2010. The impact of cultivar resistance and fungicide treatment on mycotoxin content in grain and yield losses caused by Fusarium head blight in wheat. Czech J. Genet. Plant Breed, 46: 21-26.

Wagacha J.M., Oerke E., Dehne H. W., Steiner U. 2012. Interactions of Fusarium species during prepenetration development. Fungal biology, (in press). http://dx.doi.org/10.1016/j.funbio.2012.05.001

Wat anabe T. 2002. Pictorial Atlas of Soil and Seed Fungi. 504.

Wi ew iór a B . 2006. Bipolaris sorokiniana (Sacc.) Shoem. identification, biology and importance in cultivation of cereals. Biul. IHAR 42: 131-139.
Xu X., Parry D., Nicholson P., Thomsett M., Simpson D., Edwards S., Cooke B., Doohan F., Brennan J., Moretti A., Tocco G., Mulč G., Hornok L., Giczey G., Tatnell J. 2005. Predominance and association of pathogenic fungi causing Fusarium ear blight in wheat in four European countries. Eur J. Plant Pathol. 112: 143-154. http://dx.doi.org/10.1007/s10658-005-2446-7

Yli-Mattila T., Paavanen-Huhtala S., Jestoi M., Parikka P., Hietaniemi V., Gagkaeva T., Sarlin T., Haikara A., Laaksonen S., Rizzo A.2008. Real-timePCR detection and quantification of Fusarium poae, F. graminearum, F. sporotrichioides and F. langsethiae in cereal grains in Finland and Russia. Arch. Phytophalology Plant Protect. 41(4): 243-260. http://dx.doi.org/10.1080/03 235400600680659

\section{Diagnostyka patogenów grzybowych z rodzaju Fusarium z ziarna pszenicy ozimej uprawianej w warunkach ochrony fungicydowej w rejonie Polski północno-wschodniej}

\section{Streszczenie}

Celem badań było zastosowanie różnych metod diagnostycznych do oceny wpływu ochrony fungicydowej na występowanie patogenicznych grzybów w ziarnie pszenicy. Doświadczenie polowe, w którym uprawiano pszenicę ozimą (odmiany Nutka i Zyta) przeprowadzono w latach 2006-2007 w Zakładzie Produkcyjno-Doświadczalnym w Bałcynach. Czynnikiem doświadczenia było zastosowanie ochrony chemicznej: epoksykonazolu, krezoksymu metylowego, fenpropimorfu w fazie $\mathrm{BBCH} 33-35$ oraz dimoksystrobiny i epoksykonazolu $\mathrm{w}$ fazie BBCH 51-53. W badaniach wykazano, że metody mikroskopowa oraz klasyczny PCR uzupełniaja się. Kwantyfikacja DNA grzyba Fusarium poae metodą qPCR wykazała skuteczność ochrony chemicznej w zwalczaniu tego gatunku. Niższe miesięczne sumy opadów oraz wyższe dobowe temperatury sprzyjały przede wszystkim, infekcji ziarna przez $F$. poae. Stwierdzono istotną korelację pomiędzy liczbą kultur $F$. poae wyizolowanych z ziarna pszenicy ozimej a ilością patogennego DNA określoną w ziarnie metodą qPCR. Wykazano także, że porażenia ziarna przez $F$. poae powoduje obniżenie wielkości plonu oraz MTZ. 
